\title{
Risk factors for the safety of the children from transnational families (children left behind)
}

\section{DOI: http://doi.org/10.26758/8.1.3}

Ana Popova

Institute for the Study of Societies and Knowledge, Bulgarian Academy of Sciences, Sofia, Bulgaria

Address correspondence to: Ana Popova, Institute for the Study of Societies and Knowledge, Bulgarian Academy of Sciences, 13 A Moskovska Str., Sofia, Bulgaria, Tel: +359 889 874219; Email: popovaani@abv.bg

\begin{abstract}
Objectives. The main objective of this paper is to explore the current situation with the transnational families in Bulgaria and Romania, their profile and the consequences of the transnational way of life for the children left behind.

Material and methods. The paper presents a comparative analysis of the risk factors for the children from transnational families, identified and interpreted in two studies supported by UNICEF in Bulgaria and Romania. Two methods are used in the paper - secondary analysis of existing data and comparative method.

Results. The phenomenon "children left behind in Bulgaria with parents working abroad" affects between 265,102 and 271,782 children at the end of 2012. Among them, there is a growing nuisance. They don't receive the necessary health care, often drop out the school and become dependent on drugs, alcohol, and cigarettes. In Romania, the phenomenon "alone at home" affects about 350,000 children. The risks identified for the Romanian children are: physical, psychological and emotional vulnerability, the risk of sexual abuse and harassment, the risk of trafficking and prostitution, early start of sexual life and others.

Conclusions. The children from transnational families are subject to many risk factors. The responsible institutions are not able to provide the necessary support and the qualified personnel in these institutions is not sufficient. There are many gaps in the national policy in relation to the children of migrant parents.
\end{abstract}

Keywords: transnational families; labor migration; risk factors; children left behind; home alone children; safety.

\section{Introduction}

In the process of globalization, a significant increase of the migration flows can be observed due to the natural human strife for overcoming the poverty and unemployment, as well as because of the interest towards education abroad or the need for a better living standard. One of the newly-appearing phenomena in these conditions is the transnational family - a family unit in which one or both parents become migrants and leave their relatives, mostly children, in the country of origin.

In the context of the Millennium goals of UN and the Strategy 2020 of the European Union, the phenomenon of "transnational families" is increasingly focusing the public opinion and is put in 
the attention of the family policy of the European Union. This issue has been recently introduced and discussed within the framework of the family policy of Bulgaria and Romania not only as member states of the European Union but also as countries which are directly affected by the scale of this phenomenon, having its consequences for the children left behind by their parents.

The concept of "transnational family" is comparatively new. The phenomenon started to attract the attention of migrant researchers in the early $90 \mathrm{~s}$ of the $20^{\text {th }}$ century. In the same period, the concept of "transnationalism" was introduced, explaining the migration as multifaceted social space, experienced by the communities across the borders (Glick-Schiller et al., 1999). Unlike traditional migration theories, the transnationalism offers an alternative approach to the exploration of migrants' experience, based on their simultaneous positioning in several social and territorial locations (Glick-Schiller et al., 1999). In the light of the transnationalism, the traditional understanding of the family as a unit for cohabitation at one and the same place is changing towards the perception of the family as territorially scattered and fragmented (Glick-Schiller et al., 1999).

At present, there are a number of terms that essentially refer to the concept of transnational family, such as multi-sited family (Ong and Nonini, 1997), multi-local binational family (Guarnizo, 1997), transcontinental family (Kelly, 1990), international family (Ho, 1993) and others. These terms are used interchangeably although there are differences in the research perspective for defining each concept. The researchers have reached a consensus on the idea about the geographical dispersal of the family, i.e. for a new geography of the family unit (Lam et al., 2002), as well as for the maintenance of close contacts with the relatives in the country of origin. However, the authors put different meanings in the analyzed subject that varies both in terms of family size nuclear/extended - and its composition - uni-national or bi-national (mixed).

The different points of view about the concept of transnational family are reflected in the variety of its definitions. As one of the basic definitions is accepted that of Bryceson and Vuorela, according to which those families whose members are living apart from each other for a shorter or longer time, but maintaining common relationships and a spirit of collective welfare and unity even across the borders of separate countries can be defined as transnational (Bryceson and Vuorela, 2002).

Wiltshire defines the transnational family as a large amorphous structure, consisting of kinship segments, which are scattered across the national boundaries (Wiltshire, 1992).

According to Le Gal, the transnational family is a modernized model of family relations characterized by geographic dispersion due to the migration of one or more of the family members (Le Gal, 2005).

Bjeren interprets the transnational family as collective kinship relations with residence in at least two countries (Bjeren, 1997). These transnational units are not static but may change over time by changing the status of the constituent members - emigrants, immigrants or returning to the country of origin (Zontini, 2007). An important clarification about the transnational families made by Zontini is that their members are separated geographically but maintain social, cultural, reproductive and financial links across the borders (Zontini, 2007).

Despite the fact that the members of the transnational families continue to keep their relations across the borders, the researchers are united around the view that the separated cohabitation affects the fulfilment of the fundamental functions of the family unit, namely: reproductive, socializing, economic, function of primary social control, recreational, protective and hedonistic function (Tolstokorova, 2013). 
Nowadays there is a steady trend of increasing attention towards the phenomenon of the transnational families in a global perspective. The term care drain is used in analogy with brain drain (Rossi, 2008).

In the recent years, the topic has also become sensitive for the countries in Eastern Europe because of the significant migration flows in these countries. Detailed studies on the topic are carried out in Moldova (Cheianu et al., 2011), Romania (Toth et al., 2007), Ukraine (Tolstokorova, 2009) and Bulgaria (Kabakchieva et al., 2016).

The phenomenon of the transnational family scientifically difficult to explore, since different forms and manifestations of it were identified. The most widespread form of its existence is the transnational parenting in which there are four cases of separate cohabitation:

- when the mother works abroad and has left her children and the other members of the family in the country of origin (transnational motherhood);

- $\quad$ when the migrant father is away from his family (transnational fatherhood);

- when the two parents are migrants and they either live abroad with their child/children or have left them to the care of relatives in the country of origin;

- when the child lives abroad and is far from his/her parents, most often by reason of obtaining an education.

There are a number of studies dedicated to the experience of women who have gone abroad to work as support staff. The working conditions, the lack of resources and their low social status make them leave their children in the country of origin. In these situations, defined as "global care chains" (Hochschild, 2000), the women, in addition to fulfilling their role as "mothers from a distance" (Hondagneu-Sotelo and Avila, 2003), provide a financial support for their children left in the care of grandparents or other relatives in the country of origin. This type of family configuration is embedded in many studies for Caribbean women who have gone to work in the United States (Guarnizo, 1997), women from Latin Amerika (Hondagneu-Sotelo and Avila, 2003) and from the Philippines (Parrenas, 2003).

Although fewer in number, there are studies exploring the transnational fatherhood and its impact on the children left in the country of origin. In this relation, the study of Nobles (2011), which explores the effects on children from Mexico, whose fathers have migrated or whose parents are divorced, stands out. Nobles finds that in cases of migration, the interaction with the children is more intensive than in divorce cases, regardless of the geographic distance. Furthermore, the connection with the migrant father positively affects the school results of children (Nobles, 2011).

In the third form of configuration, when both parents are migrants, the researchers explore the role of those who are left to take care of children, most often their grandmothers or aunts. Bernardi (2011) offers a methodological approach, oriented to the social networks, established in connection with the care for the children left at home. The focus on these networks allows the inclusion of units bigger than the nuclear family, e.g. the extended family that is a dominating institution when both parents are abroad (Bernardi, 2011).

Another type of family configuration stems from the migration of the children - alone or accompanied by a parent. In this case, the researchers speak about "astronaut families" or "children paratroopers" (Ho, 2002). Such families are usually rich, most often from Asia, e.g. China, Hong Kong, Taiwan or South Korea.

There are two main approaches to the clarification of the issue about the types of transnational families. In the first one, the transnational family is interpreted as a transnational household, defined as a household where at least one family member lives abroad. Here the 
migration is an opportunity for economic survival of the family as a whole, including its members left in the country of origin (Hondagneu-Sotelo and Avila, 2003).

The second approach focuses on the transnational kinship networks and the existence of many households. Within the frames of this approach, a number of researchers have worked, among which those from the USA - Sutton, 2004; France - Streiff-Fenart, 1999; Canada - Le Gall, 2005; UK - Plaza, 2000, Australia - Hage, 2004 and many others. This phenomenon relates to migrants from many countries around the world, in one or another stage of their history, who are affected by large migratory waves, e.g. from Tunisia, Lebanon, the Dominican Republic, Mexico, in recent times from Syria and others.

The current paper is focusing on the third form from the types of transnational families listed above, that in which both parents are economic migrants and their children are left in the care of relatives, most often grandparents, in the country of origin.

In connection with the clarification of the phenomenon of transnational families, it is also necessary to discuss the concept of the children left by their parents-economic migrants, in the country of origin for a period longer than 3 months. Recently, in relation to this, the term Children Left Behind was introduced as a result of a discussion in the European Parliament in 2009 and one publication of UNICEF (UNICEF Innocenti Research Centre, 2010). The latter argue that the absence of the parents may have a negative effect on the children left behind, including a risk for their physical and mental health, depression, difficulties in the development, passivity at school, dropping-out of the education system, etc. The children left behind in the country of origin belong to the group of vulnerable children at risk. Most of them develop a sense of deprivation and lack of interest, refusal to participate in school and out-of-school activities. A direct consequence of the parents' migration is the fact that the child doesn't receive parental love and the necessary surveillance of his/her development. As a result of this, the physical and mental health of the child is disturbed and, in some cases, he/she starts to demonstrate a non-typical behavior or is exposed to the risk of different types of exploitation and abuse (Minkovski, 2014).

After a study conducted with the support of UNICEF-Romania in 2008 (Toth et al., 2008) about the children from transnational families, the term Home Alone Children was introduced to qualify the group of children left in the country of origin without parental care because of the labor migration of their parents.

In relation to the concepts discussed above, the researchers differentiate a number of phenomena as a result of the appearance of the transnational families and their impact on the children, such as "dead mothers syndrome" in young children, overly-aggressive behavior among adolescents aiming to attract the attention of their parents, social anxiety (avoidance behavior), emotional isolation and others (Kabakchieva, 2009, p.311).

Last but not least, in connection with the problems discussed, the concept Children at Risk has to be clarified. It is interpreted with several meanings: a) a child whose parents are deceased, unknown, deprived of parental rights or with limited parental rights, or the child has been left without their care; b) a child who is a victim of abuse, violence, exploitation or any other inhuman or degrading treatment or punishment within or outside his or her family; c) a child who is in danger of harming his/her physical, mental, moral, intellectual and social development; d) a child, suffering from disability, as well as from diseases difficult to treat and diagnosed by a specialist; e) a child who is at risk of dropping out of school or has dropped out of school (Additional acts to the Child Protection Law, 2009). The paper seeks to answer the question whether the children from transnational families are children at risk by the indicators listed. 
The main objective of this paper is to explore the current situation with the transnational families in Bulgaria, their profile and the consequences of the transnational way of life on the children left behind.

\section{Material and methods}

On the basis of two studies, carried out with the support of UNICEF-Bulgaria "Effects on the children left behind by their parents, working and living abroad" (2016) and UNICEF-Romania "National analysis of the phenomenon "children left at home by their parents migrating abroad for employability" (2008), the current paper explores in a comparative perspective the risk factors for the children from transnational families, as well as the gaps in the national policies in the two countries, in relation to such children. Although covering different periods of time, the cited studies use one and the same methodology and are very close in their final conclusions. That is why the current paper uses the data collected in the two studies for a secondary analysis and, applying the comparative method, looks for similarities and differences in the identified effects and consequences for the children from transnational families.

\section{Results}

The exploration of the situation with the transnational families in Bulgaria gives evidence about the fact, that at the current moment the responsible institutions do not collect systematic information about the number of the children whose parents are labor migrants. In the existing migration studies, this problem is reflected peripherally (Bogdanov and Rangelova, 2012).

The children with parents abroad, left in Bulgaria, are still not in the focus of the information systems of the Agency for Social Assistance, the State Agency for Child Protection, as well as the bodies dealing with the antisocial actions - the Ministry of the Interior and the Commission for Combating Juvenile Delinquency, as these children are not identified by the indicated institutions as children at risk, i.e. the existence of risk is not proven for them. The main bodies for child protection collect information about concrete cases in their work, including family status, but it is not summarized (Kabakchieva et al., 2016).

The situation is similar in Romania where there is only one governmental source of information - the National Authority for the Protection of Children's Rights (NAPCR), which has been collecting data since 2006 (Toth et al., 2008).

The data from the Bulgarian UNICEF study indicate that at least one parent of every fifth child in Bulgaria is abroad. According to the National Statistical Institute (as of 31.12.2012), there are $1,325,511$ children in Bulgaria aged 0 to 19 years. One-fifth of them is equal to $\mathbf{2 6 5 , 1 0 2}$, but another study calculates their number at 271,782. The Bulgarian UNICEF study also indicates a break from the classic, nuclear family with children and two parents. The transnational families whose members live in different countries are $26 \%$ from all Bulgarian families, as in $3 \%$ of cases both parents are abroad. Most of the children with both parents abroad are raised by their grandmother $-65.5 \% ; 13,7 \%$ live with relatives, and $5.1 \%$ live in foster families (Kabakchieva et al., 2016).

At the national level in Romania, it is estimated that the phenomenon "alone at home" involves around 350,000 children (about $7 \%$ of the total population aged 0-18 years) having at least one parent abroad. Approximately 126,000 of these children have two parents abroad, and more than a half of all children live in rural areas. 
For all young people aged 0-18 years, another approximately 400,000 children have experienced the absence of one of the parents as a result of his/her labor migration. This means that almost 750,000 children, out of approximately 5 million children in Romania, have been suffered by their parents' migration (Toth et al., 2008).

If we compare the children affected by the phenomenon of transnational families on the basis of the aforementioned numbers, we can argue that it causes negative consequences for about $20 \%$ of the children in Bulgaria and $15 \%$ of the children in Romania.

The authors of the Bulgarian study draw attention to the fact that nearly $6 \%$ of the children placed in boarding schools have parents abroad. Also, about $20 \%$ of the children using the Animus hotline to share their problems have parents abroad.

A similar conclusion is drawn for Romania - by 30 June 2007, 30,757 children were benefiting from the services for prevention of child separation from their parents, e.g. day-care centers, counseling centers, etc.

The two studies also indicate unfavorable facts about the health and well-being of the children with parents abroad. In Bulgaria, these children have more health problems compared to the children whose parents are at home, mostly because they do not go to a doctor when they are ill. With an average of $5.2 \%$ for all children, $12 \%$ of the children with two parents abroad are often hungry. They lack home-made food and their menu includes mainly pasta and potatoes. The absence of both parents working abroad is one of the reasons for the lower success of child at school, for the repetition of class or so-called "hidden dropout of school", especially during the seasonal migration (Kabakchieva et al., 2016).

In $22 \%$ of the Romanian cases when the mother is abroad, the children have taken medications that were not prescribed by a doctor, compared to $15 \%$ of those who live with their parents. There is a higher prevalence of cases of a chronic disease or handicap among the children with both parents abroad (11\%), compared to those who live with their parents $(5 \%)$. $2 \%$ of the families with current migrants report that at least one of the children has dropped out of school, especially in cases where the mothers are abroad (Toth et al., 2008).

Both studies report a higher percentage of anti-social actions and problems with the police among the children with parents abroad. For example, in Bulgaria, the share of the children with both parents abroad who have had problems with a director or deputy director of a school is nearly three times bigger than the children with parents at home. $40 \%$ of the children with both parents abroad ( 5 times more than the children with parents at home) have visited a Pedagogic Room, which is an indicator of antisocial behavior.

\section{Discussions}

On the basis of the quantitative data from UNICEF's studies in Bulgaria and Romania it can be argued that the children from transnational families experience a number of negative effects by the separated cohabitation with their parents - poor health and emotional status, downgrading or dropping out of school, growth of the antisocial actions among them and others.

Both studies try to draw the public attention to the fact that children from transnational families have infringed rights and are at risk. Four out of the 5 characteristics of the concept "children at risk", listed at the beginning of the present study, can be identified for these children. They are the following:

- The children from transnational families are left without parental care. The absence of one or both parents causes a sense of loneliness, anxiety, social isolation and self-closure. 
For example, the Romanian study shows that $10 \%$ of these children become more reserved and start spending more time in front of the TV or computer (Toth et al., 2008). When in trouble, the children from transnational families are trying to cope alone. On the one hand, this fact is positive, as it contributes to the development of qualities such as independence and self-confidence, but on the other hand, such children feel like outsiders and often fall into isolation from their peers. The disturbed communication with the parents abroad forces these children to share with friends, which sometimes prompts the risk of falling into unfavorable influence. In the Romanian study, it is pointed out that in the cases described, the child's right to not be separated from his/her parents, formulated in the Convention on the rights of the child (1990) is infringed. An additional argument is the fact that the cases of divorce in the transnational families are very common (in $43 \%$ of such families) and they cause a mental trauma in the children.

- For the children from transnational families, there is an increased risk of harming their physical, mental, moral, intellectual and social development. As was pointed out above, the children with parents abroad have unsatisfactory health status and need psychological support to overcome the deprivation and mental disorders. However, it is necessary to emphasize the more serious risks for such children, connected with the alcohol abuse, smoking, drug abuse, early onset of sexual life, and the development of deviant or criminogenic behavior. For example, in the Bulgarian study, it is presented that $60 \%$ of the children with both parents abroad smoke in comparison with 39\% smokers among the children with both parents at home. The same is valid for the alcohol abuse $-72 \%$ of the children with both parents abroad drink, compared to an average of $59.6 \%$. The children themselves report that they use the alcohol as a means of coping with the tension. $25 \%$ of the children with both parents abroad have tried marijuana compared to $13 \%$ of the children with parents at home. The children from transnational families have also more liberated views about sexual life. On the question "Who can be your eventual sexual partner", 30\% of the children with both partners abroad have answered "Everyone I like" (Kabakchieva et al., 2016). The alcohol and drug abuse often lead to deviant behavior and problems with the police. As it is argued in the Bulgarian study, this puts the children with parents abroad at a greater risk to be stigmatized as individuals with antisocial behavior, as small criminals. In the Romanian study, it is pointed out that the cases of negative effects on the children from transnational families described demonstrate an infringed children's right to an adequate standard of living and right to health which explicitly puts them in the group of children at risk.

- For the children from transnational families, there exists a serious risk of dropping out from school. As was mentioned above, there is a downgrading of their success at school, repetition of the class and hidden drop-out in the cases of seasonal migration. The Romanian study presents data from a representative study in which more than $60 \%$ of the respondents think that the children with parents abroad perform worse than their peers at school and miss many classes. This means an infringed right to education of these children.

- For the children from transnational families, there is an increased risk of being abused and exploited. Both the Bulgarian and the Romanian study report many cases of such risks for the children left without parental control and raised in the country of origin by relatives: risk of sexual abuse and harassment, trafficking and prostitution, exploitation at work and others. 


\section{Conclusions}

Together with the serious dangers and risks for the safety of children from transnational families indicated above, the Bulgarian and the Romanian studies have also identified many problematic zones in connection with the lack or ineffective policies regarding these families. The more important of them are as follows:

- Lack of synchronized inter-institutional collection of reliable information about the children whose parents work abroad. This fact allows people to draw conclusions about the unreliability of the responsible institutions and the regulatory framework. All institutions for child protection or for combating antisocial actions work with the children from transnational families when they fall into risk, but not before that, by way of prevention.

- Infringed rights of the children, left to be raised by extended family or on their own due to the unsettled guardianship or guardianship status.

- Non-identification of the children with parents working abroad as children at risk.

- Lack of adequate measures and legislative initiatives for improvement of the policies, normative acts and real outcomes for the children from transnational families (Kabakchieva et al., 2016).

The strong evidence in the two studies presented about defining children from transnational families as children at risk justify the recommendations given for attracting the attention of the society and the responsible institutions to this significant social phenomenon. These recommendations are the following:

- Identifying the children from transnational families as potential children at risk with the aim to provide a preventive and timely support according to their specific needs.

- Developing mechanisms for monitoring and assessment of the phenomenon at the local level and collecting reliable data on children left behind because of labor migration of their parents.

- Review of the legislative framework and the good practices in this field.

- Development of community-based services addressing the needs of children of migrant parents - e.g. day-care centers.

- Developing human resources to support the children from transnational families who are excluded or marginalized, especially in the rural areas.

- Introduction of legislative changes connected with the protection of children's rights when one of the parents is abroad and the other one, who is in the country, is unable to provide care and protection for the child/children.

- Participation of all responsible institutions for children's rights protection at the local level in the process of identifying the children with migrant-parents (departments for child protection, schools, police); creation of a coordination mechanism of the process of identification.

- Assessment of the risks for all children with migrant-parents, including the capacity of the person/persons taking care of them in the country of origin.

- Developing the capacity of the public services for social support at national level.

- Raising the awareness of the population about the phenomenon "home alone children" because of labor migration of their parents. 
- Creating of a concrete and clear mechanism of institutional cooperation and interaction in order to guarantee a joint intervention for decreasing the negative effects on the children stemming from the migration of their parents.

- Developing of local networks for supporting local stakeholders who can resolve the complex problems of transnational families and guarantee their support (Toth et al., 2008).

The data presented from the two UNICEF's studies, as well as the identified risks for the children from transnational families demonstrate the seriousness of this problem, generated by the labor migration in Bulgaria and Romania. It is clear that some legislative initiatives and institutional measures have to be undertaken, in order to guarantee the social safety of the children left behind and their adequate socialization, as well as to prevent their possible deprivation and deviant behavior.

\section{Bibliography}

1. Adamson, P., 2010. The Children Left Behind: A league table of inequality in child well-being in the world's rich countries, UNICEF SERIES: Innocenti Report Card no. 9. Available at: https://www.unicef-irc.org/publications/619-the-children-left-behind-a-league-table-ofinequality-in-child-well-being-in-the.html [Accessed 15 June 2017]

2. Additional act to the Child Protection Law. 2009. State Gazette of the Republic of Bulgaria. 14.

3. Bernardi, L., 2011. A mixed-method social networks study design for research on transnational families. Journal of Marriage and Family, 73, pp.788-803.

4. Bjeren, G., 1997. Gender and reproduction. In: T. Hammar et al., eds. International Migration, Immobility and Development. New York: Berg, pp.219-246.

5. Bogdanov, G. and R. Rangelova., 2012. Social impact of emigration and rural-urban migration in Central and Eastern Europe. Final country report Bulgaria. Executive summary. Available at: http://ec.europa.eu/social/BlobServlet?docId=8837\&langId=en [Accessed 24 June 2017]

6. Bryceson D. and U. Vuorela, 2002. Transnational families in the twenty-first century. In: D. Bryceson and U. Vuorela, eds. The transnational family: new European frontiers and global networks. Oxford \& New York: Berg Publishers Ltd, pp.3-30.

7. Cheianu, A., D. R. Gramma, S. Milicenco, V. Pritcan, V. Rusnac, and D. Vaculovschi, 2011. Specific needs of children and elderly left behind as a consequence of migration. Chisinau, Moldova: Ministry of Labor, Social Protection, and Family of the Republic of Moldova. Available at: http://docplayer.net/372862-Specific-needs-of-children-and-elderly-left-behind-asa-consequence-of-migration.html [Accessed 10 June 2017]

8. Glick-Schiller N., Basch, L. and Szanton Blanc, C., 1999. From immigrant to transmigrant: theorizing transnational migration. In: L. Pries, ed. Migration and Transnational Social Spaces. Aldershot, Hants, England; Brookfield, Vt.: Ashgate. pp. 73-105.

9. Guarnizo, L.E., 1997. The emergence of a transnational social formation and the mirage of return migration among Dominican transmigrants. Identities, 4(2), pp. 281-322.

10. Hage, G., 2004. Issues of Structure and Culture in Researching the Lebanese Transnational Family, lecture presented at the Lebanese Emigration Research Center, Université Notre Dame, Beyrouth, 19 May 2004.

11. Ho, E. S., 2002. Multi-local residence, transnational networks: Chinese astronaut families in New Zealand. Asian and Pacific Migration Journal, 11(1), pp.145-164.

12. Hochschild, A. R., 2000. Global care chains and emotional surplus value. In: A. Giddens and W. Hutton, eds. On the Edge: Living with Global Capitalism. London, Sage, pp.130-146. 
13. Hondagneu-Sotelo, P. and Avila, E., 2003. I'm here, but I'm there: the meanings of Latina Transnational motherhood. In: P. Hondagneu-Sotelo, Gender and US Immigration. Contemporary Trends. Berkeley, Los Angeles and London: University of California Press, pp. 317-341.

14. Kabakchieva, P., 2009. Temporary migrants: beyond roles, across identities. In: A. Kiossev and P. Kabakchieva, eds. "Rules"and "Roles". Fluid Institutions and Hybrid Identities in East European Transformation Processes (1989 - 2005). Berlin: Lit Verlag, pp.11-42.

15. Kabakchieva, P., K. Haralampiev, A. Stambolova, E. Stoykova, T. Tomova, S. Popova, V. Garnizov, G. Angelov, R. Smedovska, N. Bozakova., 2016. Effects on the children left behind by their parents, working and living abroad. Paper developed on commission of UN Children's fund (UNICEFF - Bulgaria) by a team from the "Risk - monitor" Foundation. Available from: https://www.unicef.bg/.../Children_left_behind_march_2016.pdf [Accessed 20 June 2017].

16. Kelly, E., 1990. Transcontinental families. Gujarat and Lancashire: A comparative study of social policy. In: S.C. Vertovec and C. Peach, eds. South Asians Overseas: Migration and ethnicity. Cambridge: Cambridge University Press. pp.251-267.

17. Lam, T., Yeoh, B. and Law, L., 2002. Sustaining families transnationally: Chinese-alaysian in Singapore. Asian and Pacific Migration Journal, 11(1), pp.117-143.

18. Le Gall, J., 2005. Familles transnationales: Bilan des recherches et nouvelles perspectives. Les Cahiers du Gres, 5(1), pp.29-42.

19. Minkovski, R., 2014. Support for children left in Bulgaria by parents living and working abroad. The paper has been written under the guidance of "Partners - Bulgaria" Foundation, within the frames of the project "Programme for support of transnational families". Available at: http://partnersbg.org/ver2/wp-content/uploads/2015/01/Children-Left-Behind-in-Bulgaria2015_PBF-study.pdf. [Accessed 10 June 2017].

20. Nobles J., 2011. Parenting from abroad: Migration, nonresident father involvement, and children's education in Mexico. Journal of Marriage and Family. 73, pp. 729-746. https://doi.org/10.1111/j.1741-3737.2011.00842.x

21. Ong, A. and Nonini, D., 1997. The cultural politics of Chinese transnationalism. New York: Routledge.

22. Parrenas, R.S., 2003. The care crisis in the Phillipines: children and transnational families in the new global economy. In: B. Ehrenreich and A.R. Hochschild, eds. Global Woman: Nannies, Maids and Sex Workers in the New Economy. New York: Metropolitan Books, pp.39-54.

23. Plaza, D., 2000. Transnational Grannies: the changing family responsibilities of elderly African Caribbean - born women in Britain. Social Indicators Research, 51(1), pp. 75-105.

24. Rossi, A., 2008. The impact of migration on children left behind in developing countries: outcomes analysis and data requirements. Available at: http://dx.doi.org/10.2139/ssrn.2490380 [Accessed 2 June 2017].

25. Streiff-Fenart, J., 1999. Construction d'un réseau de parenté transnational: une étude de cas d'immigrés tunisiens dans le sud de la France. Revue Européenne des migrations internationales, 15(3), pp.45-61.

26. Sutton, C.R., 2004. Celebrating ourselves: the family reunion rituals of African- Caribbean transnational families. Global Networks, 4(3), pp.243-257.

27. Tolstokorova, A., 2009. Costs and benefits of labour migration for Ukrainian transnational families: connection or consumptions. Cahiers de l'Urmis [on-line journal] Available at: https://urmis.revues.org/868 [Accessed 12 June 2017]. 
28. Tolstokorova, A., 2013. Ukrainian transnational family as a modernized model of family relationships. Journal of sociology, 2. pp. 43-64.

29. Toth, G., Păun, G., Toth, A., Voicu, O. and Ştefănescu, M., 2007. The effects of migration: children left behind. Soros Foundation Romania. Available at: http://www.fundatia.ro/sites/default/files/en_67_studiu\%20eng1\%20miki.pdf [Accessed 01 June 2017].

30. Toth, A., Munteanu, D., Bleanu, A., Tudor, E., Magheru, M., Luca, C., 2008. National analysis of the phenomenon of children left home by their parents who migrate abroad for employment. UNICEF-Romania and Alternative Sociale, pp. 1-59.

31. Wiltshire, R., 1992. Implications of transnational migration for nationalism: The Caribbean Example. In: N. Glick-Schiller et al., eds. Towards a transnational perspective on migration. Race, Class, Ethnicity, and Nationalism reconsidered. New York: New York Academy of Sciences, pp.175-187.

32. Zontini, E., 2007. Continuity and change in transnational Italian families: The caring practices of second-generation women. Journal of Ethic and Migration Studies, 33(7), pp.1103-1119.

33. *** The United Nations Human Rights. 1989. Convention on the Rights of the Child (UNCRC). Available at: http://www.ohchr.org/EN/ProfessionalInterest/Pages/CRC.aspx [Accessed 18 June 2017] 